\title{
Rapid early Holocene retreat of a Laurentide outlet glacier through an Arctic fjord
}

\author{
Jason P. Briner ${ }^{1 \star}$, Aaron C. Bini ${ }^{1}$ and Robert S. Anderson ${ }^{2}$
}

Ice-sheet behaviour is disproportionately controlled by the dynamics of outlet glaciers that terminate in the ocean $^{1,2}$. However, outlet-glacier dynamics-particularly over timescales longer than the observational record-are not well understood ${ }^{3}$, leading to uncertainties in our models of ice-sheet response to climate change. Here we use ${ }^{10} \mathrm{Be}$ exposure ages and radiocarbon dating from the Sam Ford Fjord in the Canadian Arctic to reconstruct the retreat chronology of an outlet glacier of the Laurentide ice sheet, following the last glacial termination. We find that Sam Ford Fjord, which has a similar morphology to the troughs holding many outlet glaciers of the Greenland ice sheet, was rapidly deglaciated about 9,500 years ago, with retreat rates ranging from 5 to $58 \mathrm{~m} \mathrm{yr}^{-1}$. The highest rates occurred in the deepest part of the fjord $(900 \mathrm{~m})$, whereas regions beyond the fjord mouth and up-valley of the head of the fjord experienced the lowest rates of retreat. We conclude that in such a fjord setting, there is a strong bathymetric control on the retreat of marine outlet glaciers: once the terminus of the outlet glacier retreated into deeper waters, increasing calving rates and basal sliding speeds caused the glacier to rapidly thin and retreat, stabilizing only when it reached the shallow inland head of the fjord.

Ice-sheet mass balance is significantly influenced by the behaviour of outlet glaciers and ice streams, which dominate overall discharge from ice sheets ${ }^{1,4}$. Large marine-terminating ice streams that drain the Greenland ice sheet have recently undergone significant fluctuations in velocity and terminus position ${ }^{2,5-7}$, but the response of ice streams to climate change is complicated by poorly understood dynamic controls on ice motion ${ }^{7-10}$. A significant limitation to our understanding of the dynamics of ice sheets and their outlets is that direct observations are limited to the past few decades.

Centennial- and millennial-scale perspectives of ice-sheet behaviour arise from ice-sheet reconstructions that constrain the timescale of ice-sheet change. Geological reconstructions of ice sheets reveal that positive feedbacks lead to much faster ice-sheet decay than growth on glacial-interglacial and millennial timescales ${ }^{11}$. Ice-thickness reconstructions of the West Antarctic ice sheet based on cosmogenic exposure dating provide a millennial-scale context for the rapid changes that are taking place there at present ${ }^{12,13}$. In other contexts, palaeodata provide long-term perspectives of ongoing ice-sheet change based on Quaternary ice-sheet behaviour in settings analogous to present ice sheets. For example, retreat of palaeo-ice shelves in Antarctica and marine-based margins of the Laurentide ice sheet during deglaciation ${ }^{14,15}$ are potentially analogous to the present deglaciation of Greenland and West Antarctica.

Here, we report a detailed chronology of ice-sheet retreat through Sam Ford Fjord, Arctic Canada (Figs 1 and 2), one of dozens of fjords that were conduits for the discharge of ice from

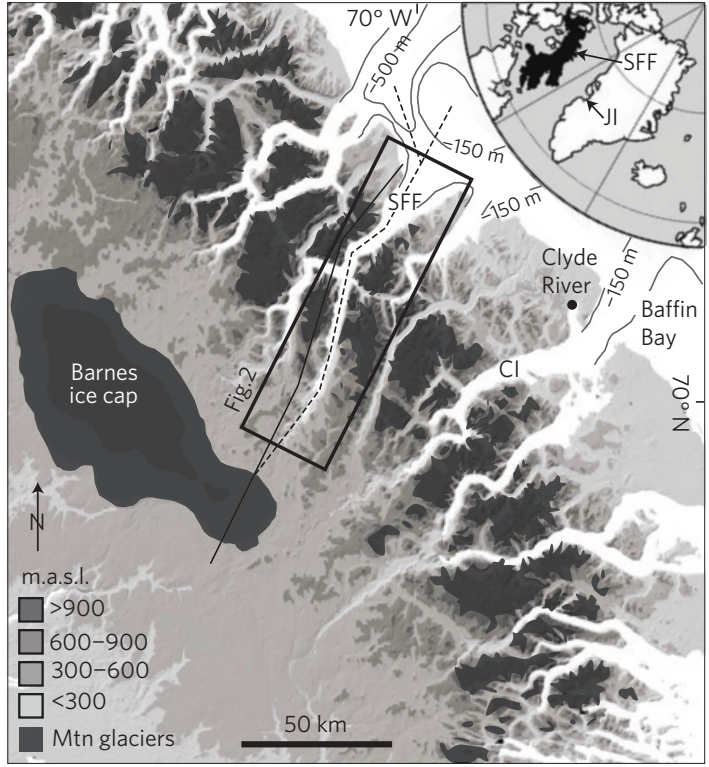

Figure 1 | Sam Ford Fjord drained part of the northeastern Laurentide ice sheet. The Barnes ice cap is the present ice limit; the Laurentide ice sheet during the Last Glacial Maximum terminated somewhere on the continental shelf. The thin black and dashed black lines running through Sam Ford Fjord are the locations of topographic and bathymetric profiles, respectively, shown in Fig. 2. (SFF: Sam Ford Fjord; Cl: Clyde Inlet.) The location of Fig. 2 is shown by the black rectangle. The inset shows Baffin Island (black) and the locations of Sam Ford Fjord and Jakobshavn Isbræ (JI), Greenland.

the northeastern Laurentide ice sheet during the last glaciation ${ }^{16}$. Sam Ford Fjord cross-cuts the glaciated mountains along northeastern Baffin Island, spanning $\sim 110 \mathrm{~km}$ from central Baffin Island to the continental shelf of Baffin Bay. The fjord is $4-6 \mathrm{~km}$ wide along most of its length, until it widens to $>10 \mathrm{~km}$ at the fjord mouth (Fig. 1). It is $100-200 \mathrm{~m}$ deep in its upper $\sim 30 \mathrm{~km}$, then quickly deepens to $\sim 900 \mathrm{~m}$ for roughly $40 \mathrm{~km}$, after which it shallows to a sill at $\sim 200-300 \mathrm{~m}$ below sea level ${ }^{17}$. It remains deeper than $400 \mathrm{~m}$ for $\sim 70 \mathrm{~km}$ as it passes through the highest portion of the mountain range (Fig. 2). Despite recently improved reconstructions of the configuration and chronology of the Laurentide ice sheet ${ }^{14}$, chronological control from within Arctic fjords remains too poor to resolve detailed fjord deglaciation histories.

Twelve sites between 110 and $7 \mathrm{~km}$ from the fjord head of Sam Ford Fjord have ${ }^{10} \mathrm{Be}$ ages ranging from $11.5 \pm 0.2$ to $7.1 \pm 1.1 \mathrm{kyr}$ (Fig. 2, see Supplementary Information). The most distal ${ }^{10} \mathrm{Be}$ age of $10.3 \pm 0.5 \mathrm{kyr}(110 \mathrm{~km}$; distances listed as

${ }^{1}$ Department of Geology, University at Buffalo, Buffalo, New York 14260, USA, ${ }^{2}$ INSTAAR and Department of Geological Sciences, University of Colorado, Boulder, Colorado 80303, USA. *e-mail: jbriner@buffalo.edu. 

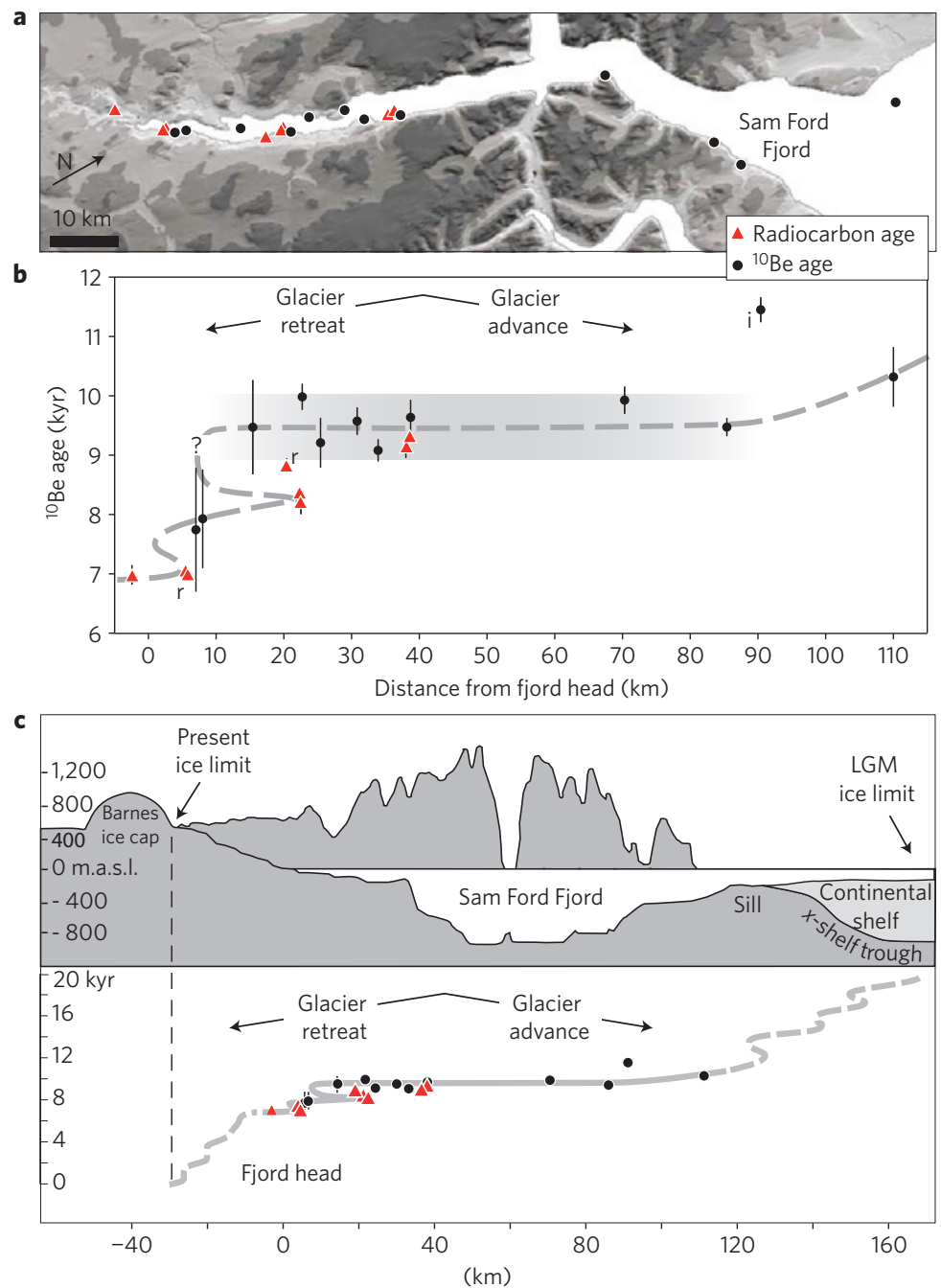

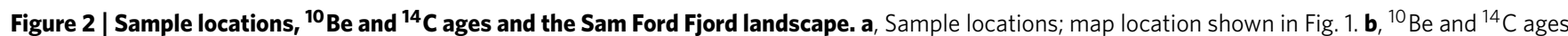
(kyr; 1 s.d. uncertainty); ' $i$ ' indicates isotopic inheritance, ' $r$ ' indicates reworked bivalve. The dashed grey line represents the time-distance path of the glacier terminus. The horizontal grey bar represents uncertainty (2 s.d.) in the timing of rapid deglaciation. c, Topography and bathymetry of Sam Ford Fjord (profiles shown in Fig. 1; modified from ref. 17) with ${ }^{10} \mathrm{Be}$ and ${ }^{14} \mathrm{C}$ ages (kyr). The grey line represents the time-distance path of the glacier terminus, solid portion from $\mathbf{b}$.

down-fjord from the fjord head) is from a small sculpted-bedrock island, and constrains the timing of deglaciation at the fjord mouth. Single ${ }^{10} \mathrm{Be}$ ages from two more sites in the outer fjord are $9.5 \pm 0.2(85 \mathrm{~km})$ and $11.5 \pm 0.2 \mathrm{kyr}(90 \mathrm{~km})$. Three ${ }^{10} \mathrm{Be}$ ages from two bedrock samples at a single site in the steep, middle reaches of the fjord $(70 \mathrm{~km}$ ) average $9.9 \pm 0.2 \mathrm{kyr}$ (see the Methods section and Supplementary Information). The ${ }^{10} \mathrm{Be}$ ages from the outermost four sites taken together suggest that the sample at $90 \mathrm{~km}$ is probably influenced by isotopic inheritance (Fig. 2). Although this sample is from a relatively low elevation (40 m.a.s.l.), glacial erosion at fjord mouths on Baffin Island has been documented to be minimal because of thinning and diverging ice flow; the likelihood of significant isotopic inheritance is therefore relatively high ${ }^{18,19}$. The ${ }^{10} \mathrm{Be}$ ages from eight sites that span from 85 to $15 \mathrm{~km}$ range from $10.0 \pm 0.2$ to $9.1 \pm 0.2 \mathrm{kyr}$ (Fig. 2). These ages statistically overlap and there is no trend in the ages, suggesting that the middle, deepest $>70 \mathrm{~km}$ reach of the fjord deglaciated rapidly $9.5 \pm 0.6 \mathrm{kyr}$ ago (average ${ }^{10} \mathrm{Be}$ age from the eight sites at two s.d.). This age for deglaciation of most of the fjord is consistent with two radiocarbon ages of 9,310 \pm 50 and $9,130 \pm 170 \mathrm{cal} \mathrm{yr} \mathrm{вр} \mathrm{from} \mathrm{a} \mathrm{raised} \mathrm{marine}$ delta at $38 \mathrm{~km}$, providing a minimum age of deglaciation (Fig. 2; see Supplementary Information for radiocarbon calibration and reservoir corrections).

Glacier re-advances within the inner fjord resulted in much slower average retreat following the rapid deglaciation of the middle fjord. Radiocarbon ages of 8,330 \pm 30 and 8,210 $\pm 190 \mathrm{cal} \mathrm{yr} \mathrm{в}$ from an ice-contact delta at $22.5 \mathrm{~km}$ are significantly younger than the period of rapid deglaciation of the fjord $9.5 \pm 0.6 \mathrm{kyr}$ ago, and indicate the culmination of an advance to $22 \mathrm{~km}$ at $\sim 8.3 \mathrm{kyr}$ в . A bivalve fragment reworked into a moraine up-fjord from the ice-contact delta at $20.4 \mathrm{~km}$ is $8,830 \pm 120 \mathrm{calyr}$ в , supporting the notion that the inner fjord was ice-free between deglaciation $9.5 \pm 0.6 \mathrm{kyr}$ ago and the subsequent advance that culminated $8.3 \mathrm{kyr}$ ago. ${ }^{10} \mathrm{Be}$ ages of $7.9 \pm 0.8$ and $7.7 \pm 1.1 \mathrm{kyr}$ from 8 and $7 \mathrm{~km}$, respectively, indicate that deglaciation resumed following the brief advance. Finally, three radiocarbon ages from two ice-contact deltas and one moraine between -2.5 and $5.6 \mathrm{~km}$ indicate glacier advances $\sim 7,000 \pm 50$ and 7,050 $\pm 90 \mathrm{cal} \mathrm{yr} \mathrm{вр} \mathrm{(Fig.} \mathrm{2),} \mathrm{after} \mathrm{which}$ final deglaciation of Sam Ford Fjord took place.

We assess the rate of deglaciation within Sam Ford Fjord by comparing it with the broader pattern of deglaciation between the Last Glacial Maximum margin on the continental shelf and the present ice limit at the Barnes ice cap, $200 \mathrm{~km}$ inland. Although the 
precise Last Glacial Maximum limit is unknown, ice probably filled cross-shelf troughs to the shelf break, $\sim 50 \mathrm{~km}$ beyond the mouth of Sam Ford Fjord, on the basis of research in neighbouring fjords ${ }^{19}$. Cosmogenic exposure ages of erratics on coastal lowlands south of Sam Ford Fjord reveal that ice retreated onto the inter-fjord areas by $\sim 16$ kyr ago from a more extensive ice limit offshore ${ }^{19,20}$. Thus, the ice margin probably retreated $\sim 50 \mathrm{~km}$ from the shelf to the mouth of Sam Ford Fjord between $>16 \mathrm{kyr}$ and $10.3 \pm 0.5$ kyrago, yielding a maximum average retreat rate of $9 \mathrm{~m} \mathrm{yr}^{-1}$ (Fig. 2). Although there is no chronology for deglaciation of the 35-km-long valley between Sam Ford Fjord and the Barnes ice cap, only $30 \mathrm{~km}$ of the $60-\mathrm{km}$-long valley between the head of Clyde Inlet and the southern Barnes ice cap, immediately to the southeast of the head of San Ford Fjord (Fig. 1), deglaciated between 8 and $4 \mathrm{kyr}_{\text {ago }}{ }^{21}$. The retreat of the northern Barnes ice cap throughout the middle and late Holocene was equally slow ${ }^{14,22}$. Thus, ice probably retreated from the head of Sam Ford Fjord to the Barnes ice cap at an average rate of $\sim 5 \mathrm{~m} \mathrm{yr}^{-1}$. These rates of deglaciation for both the regions beyond the fjord mouth and up-valley of the fjord head are roughly an order of magnitude slower than the rate of deglaciation of the middle of Sam Ford Fjord (Fig. 2), where $>70 \mathrm{~km}$ was deglaciated in $<1,200$ years (two s.d. range of the average age of deglaciation), yielding a minimum average retreat rate of $58 \mathrm{~m} \mathrm{yr}^{-1}$.

The marked retreat of this outlet glacier through Sam Ford Fjord contrasts with slower average rates of retreat outboard and inboard of the fjord, and implies a strong role for ice dynamics in the demise of outlet glaciers. It seems that as soon as ice retreated into the deeper water inland of the fjord mouth sill, irreversible and rapid retreat occurred until the outlet glacier reached shallower water at the fjord head (Fig. 2). The Sam Ford Fjord outlet glacier should show tidewater glacier cycle behaviour in which the terminus advances slowly during times of positive mass balance, and retreats rapidly when climate allows the glacier terminus to thin ${ }^{9}$. As calving rates increase with water depth ${ }^{23}$, retreat of the calving front into deeper water inboard of a sill promotes acceleration of retreat. Perhaps more importantly, a dynamic feedback enhances sliding speed when a glacier terminus is immersed in the ocean. Below a threshold ice thickness, the dependence of ice discharge on ice thickness reverses to become negative; as the ice thins, the resisting traction with the bed declines more rapidly than does the driving stress, promoting accelerated sliding ${ }^{9}$. If the geometry of the glacier is such that this results in a down-valley increase in ice discharge, then continuity of ice requires the ice to thin, resulting in yet greater ice discharge. The ongoing retreat of Columbia Glacier in Alaska and of outlet glaciers on Greenland has been accompanied by significant dynamic thinning of this sort ${ }^{2,6,9}$.

Regional climate reconstructions reveal significant summer air temperature increase between $\sim 11$ and $10 \mathrm{kyr}$ ago $^{24}$, which would have increased surface ablation, slightly before rapid deglaciation of Sam Ford Fjord. In addition, thermophilous marine bivalves arrived in northwestern Baffin Bay between 10 and $9 \mathrm{kyr}_{\text {ago }}{ }^{25}$, indicating the incursion of relatively warm Atlantic waters to the region around the time of rapid deglaciation. Enhanced melting of the tidewater glacier terminus by warm ocean water, reportedly associated with current glacier retreat on Greenland ${ }^{26}$, therefore may have been involved in triggering retreat $\sim 9.5 \mathrm{kyr}$ ago. Without more high-resolution climate reconstructions over this interval, the relative importance of atmospheric, oceanographic and dynamic forcing mechanisms remains uncertain. However, the rapidity and irreversibility of the subsequent retreat, once initiated, is more likely attributable to tidewater glacier sliding feedbacks.

Combined with rapid retreat of other marine-based portions of the Laurentide ice sheet ${ }^{14,18}$, the rapid retreat of the Sam Ford Fjord outlet glacier provides new insights that have implications for the future deglaciation of ice sheets. All indications suggest that twenty-first century warming will continue, and marked changes at marine ice-sheet margins are already taking place ${ }^{2,7,15,27}$. Ice streams draining the Western Antarctic ice sheet and many of Greenland's outlet glaciers that lie in deep channels below sea level might experience retreat on the scale of that which occurred in Sam Ford Fjord $\sim 9.5 \mathrm{kyr}$ ago. For example, Jakobshavn Isbræ lies in a channel $>1.0 \mathrm{~km}$ below sea level that extends $\sim 100 \mathrm{~km}$ inland ${ }^{5}$. Although rapid evacuation of ice marginal troughs will not necessarily lead to broader ice-sheet retreat once the outlet glaciers have become land-terminating ${ }^{7,28}$, the sectors of ice sheets that feed large marine-terminating outlet glaciers would undoubtedly be influenced by steepened surface slopes towards the new retracted margins.

The future success of ice-sheet models relies on not only better representation of the dynamic processes involved, but on rigorous testing against all relevant observations. Geological reconstructions such as the one reported here constrain the rates of ice-sheet margin changes for geometries similar to those of today's ice sheets, on which our direct observations are limited to a few decades. The outlet glacier in Sam Ford Fjord retreated $\sim 40 \%$ of the distance between the Last Glacial Maximum and the present ice limit in only $\sim 5 \%$ of the deglacial interval. The future behaviour of ice sheets will be strongly influenced by their marine-terminating outlets, many of which lie in troughs that extend well below sea level and penetrate ten to hundreds of kilometres inland, and are strikingly analogous to Sam Ford Fjord before its rapid deglaciation. Thus, tens to hundreds of kilometres of retreat of present outlet glaciers is possible in the coming centuries.

\section{Methods}

Samples for ${ }^{10}$ Be surface exposure dating were collected from 15 polished and striated granite and gneiss bedrock surfaces and one polished erratic cobble perched on bedrock that span the length of Sam Ford Fjord (Fig. 1; see Supplementary Table S1). In four locations, an average ${ }^{10} \mathrm{Be}$ age was calculated from ${ }^{10} \mathrm{Be}$ ages of two bedrock samples at the same general site. At one site, quartz from two different samples (SF07-01, $-02 ; 70 \mathrm{~km}$ from the fjord head) was processed to produce a third ${ }^{10} \mathrm{Be}$ age; all three ${ }^{10} \mathrm{Be}$ ages were averaged into one ${ }^{10} \mathrm{Be}$ age for this site. Samples were collected from windswept locations in spring (the time of maximum seasonal snow cover) to ensure that sample sites remain snow-free year round. We collected samples from low elevations to reduce the possibility of isotope inheritance ${ }^{19}$ and in all cases samples are from above the marine limit, which is $\sim 60$ m.a.s.l. in the inner Fjord, and $\sim 22$ m.a.s.l. at the outer coast ${ }^{19}$. Elevation, latitude and longitude were gathered with a hand-held global positioning system; topographic shielding measurements were taken using a clinometer. Samples were prepared at the University at Buffalo, accelerator mass spectrometric ratios were measured at PRIME Lab (Purdue University) and the Center for Accelerator Mass Spectrometry (Lawrence Livermore National Laboratory) and ${ }^{10} \mathrm{Be}$ ages were calculated using the CRONUS online exposure age calculator ${ }^{29}$ with a locally calibrated ${ }^{10}$ Be production rate ${ }^{30}$ (see Supplementary Information). Three new radiocarbon ages, combined with five previously published radiocarbon ages, are used to further constrain the deglaciation of the inner $\sim 40 \mathrm{~km}$ of Sam Ford Fjord (see Supplementary Table S2).

Received 11 February 2009; accepted 27 May 2009; published online 21 June 2009

\section{References}

1. Bennet, M. R. Ice streams as the arteries of an ice sheet: Their mechanisms, stability and significance. Earth Sci. Rev. 61, 309-339 (2005).

2. Rignot, E. \& Kanagaratnam, P. Changes in the velocity structure of the Greenland ice sheet. Science 311, 986-990 (2006).

3. IPCC. Climate Change 2007: The Physical Science Basis. Contribution of Working Group I to the Fourth Assessment Report of the Intergovernmental Panel on Climate Change (eds Solomon, S., Qin, D., Manning, M., Chen, Z., Marquis, M., Averyt, K. B., Tignor M., and Miller, H. L.) (Cambridge Univ. Press, 2007).

4. Kessler, M. A., Anderson, R. S. \& Briner, J. P. Fjord insertion into continental margins driven by topographic steering of ice. Nature Geosci. 1, 365-369 (2008).

5. Joughin, I., Abdalati, W. \& Fahnestock, M. Large fluctuations in speed on Greenland's Jakobshavn Isbrae glacier. Nature 432, 608-610 (2004).

6. Howat, I. M., Joughin, I. \& Scambos, T. A. Rapid changes in ice discharge from Greenland outlet glaciers. Science 315, 1559-1561 (2007).

7. Nick, F. M., Vieli, A., Howat, I. M. \& Joughin, I. Large-scale changes in Greenland outlet glacier dynamics triggered at the terminus. Nature Geosci. 2, 110-114 (2009). 
8. Parizek, B. R. \& Alley, R. B. Ice thickness and isostatic imbalances in the Ross Embayment, West Antarctica: Model results. Glob. Planet. Change 42, 265-278 (2004).

9. Pfeffer, W. T. A simple mechanism for irreversible tidewater glacier retreat. J. Geophys. Res. 112, F03S25 (2007).

10. Van de Wal, R. S. W. et al. Large rapid melt-induced velocity changes in the ablation zone of the Greenland Ice Sheet. Science 321, 111-113 (2008).

11. Clark, P. U., Alley, R. B. \& Pollard, D. Northern Hemisphere ice-sheet influences on global climate change. Science 286, 1104-1111 (1999).

12. Stone, J. O. et al. Holocene deglaciation of Marie Byrd Land, West Antarctica. Science 299, 99-102 (2003).

13. Johnson, J. S., Bentley, M. J. \& Gohl, K. First exposure ages from the Amundsen Sea Embayment, West Antarctica: The late Quaternary context for recent thinning of Pine Island, Smith, and Pope Glaciers. Geology 36, 223-226 (2008).

14. Dyke, A. S., Moore, A. \& Robinson, L. Deglaciation of North America. Geol. Surv. Can. Open File 1574 (2003).

15. Bentley, M. J. et al. Early Holocene retreat of the George VI Ice Shelf, Antarctic Peninsula. Geology 33, 173-176 (2005).

16. Andrews, J. T. \& Ives, J. D. 'Cockburn' nomenclature and the Late Quaternary history of the eastern Canadian Arctic. Arctic Alpine Res. 10, 617-633 (1978).

17. Buckley, J. T. Gradients of past and present outlet glaciers. Geol. Surv. Pap. Can. 69-29 (1969)

18. Kaplan, M. R. \& Miller, G. H. Early Holocene delevelling and deglaciation of the Cumberland Sound region, Baffin Island, Arctic Canada. Geol. Soc. Am. Bull. 115, 445-462 (2003).

19. Briner, J. P., Miller, G. H., Davis, P. T. \& Finkel, R. C. Cosmogenic radionuclides from fiord landscapes support differential erosion by overriding ice sheets. Geol. Soc. Am. Bull. 118, 406-420 (2006).

20. Davis, P. T., Briner, J. P., Coulthard, R. D., Finkel, R. C. \& Miller, G. H. Preservation of arctic landscapes overridden by cold-based ice sheets. Quat. Res. 65, 156-163 (2006).

21. Briner, J. P., Miller, G. H., Finkel, R. \& Hess, D. P. Glacial erosion at the fiord onset zone and implications for the organization of ice flow on Baffin Island, Arctic Canada. Geomorphology 97, 126-134 (2008).

22. Andrews, J. T. \& Barnett, D. M. Holocene (Neoglacial) moraine and proglacial lake chronology, Barnes Ice Cap, Canada. Boreas 8, 341-358 (1979).

23. Benn, D. I., Warren, C. R. \& Mottram, R. H. Calving processes and the dynamics of calving glaciers. Earth Sci. Rev. 82, 143-179 (2007).
24. Axford, Y., Briner, J. P., Miller, G. H. \& Francis, D. R. Paleoecological evidence for abrupt cold reversals during peak Holocene warmth on Baffin Island, Arctic Canada. Quat. Res. 71, 142-149 (2009).

25. Dyke, A. S., Dale, J. E. \& McNeely, R. N. Marine molluscs as indicators of environmental change in glaciated North America and Greenland during the last 18,000 years. Geog. Phys. Quat. 50, 125-184 (1996).

26. Holland, D. M., Thomas, R. H., De Young, B., Ribergaard, M. H. \& Lyberth, B. Acceleration of Jakobshavn Isbrae triggered by warm subsurface ocean waters. Nature Geosci. 1, 659-664 (2008).

27. Scambos, T. A., Bohlander, J. A., Shuman, C. A. \& Skvarca, P. Glacier acceleration and thinning after ice shelf collapse in the Larsen B embayment, Antarctica. Geophys. Res. Lett. 31, L18402 (2004).

28. Pfeffer, W. T., Harper, J. T. \& O’Neel, S. Kinematic constraints on glacier contributions to 21st century sea-level rise. Science 321, 1340-1343 (2008).

29. Balco, G., Stone, J., Lifton, N. \& Dunai, T. A complete and easily accessible means of calculating surface exposure ages or erosion rates from ${ }^{10} \mathrm{Be}$ and ${ }^{26} \mathrm{Al}$ measurements. Quat. Geochron. 3, 174-195 (2008).

30. Balco, G. et al. Regional beryllium-10 production rate calibration for late-glacial northeastern North America. Quat. Geochron. 4, 93-107 (2009).

\section{Acknowledgements}

We express sincere thanks to many people who helped this project along the way: J. Qillaq of Clyde River; R. Finkel and D. Rood at Lawrence Livermore National Laboratory; M. Caffee and others at PRIME Lab; T. Bank, B. Csatho, L. Håkansson, E. Thomas and N. Young in the Department of Geology, University at Buffalo; S. Lehman and C. Wolak at the INSTAAR Laboratory for AMS Radiocarbon Preparation and Research. This project was financially supported by NSF grant EAR-0644966.

\section{Author contributions}

J.P.B. and R.S.A. instigated and directed this research. All authors participated in fieldwork and designed the field sampling strategy. A.C.B. carried out all sample processing and initial data interpretation. All authors contributed to manuscript preparation.

\section{Additional information}

Supplementary information accompanies this paper on www.nature.com/naturegeoscience. Reprints and permissions information is available online at http://npg.nature.com/ reprintsandpermissions. Correspondence and requests for materials should be addressed to J.P.B. 